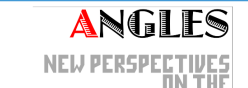

ANELOPHONE WORLD

\section{Angles}

New Perspectives on the Anglophone World

$12 \mid 2021$

COVID-19 and the Plague Year

\title{
Operation Warp Speed as a "Moonshot": Some Public Policy Lessons
}

\section{Nicholas Sowels}

\section{(2) OpenEdition}

1 Journals

\section{Electronic version}

URL: https://journals.openedition.org/angles/4179

DOI: $10.4000 /$ angles.4179

ISSN: 2274-2042

\section{Publisher}

Société des Anglicistes de l'Enseignement Supérieur

\section{Electronic reference}

Nicholas Sowels, "Operation Warp Speed as a "Moonshot": Some Public Policy Lessons", Angles [Online], 12 | 2021, Online since 03 November 2021, connection on 22 December 2021. URL: http:// journals.openedition.org/angles/4179; DOI: https://doi.org/10.4000/angles.4179

This text was automatically generated on 22 December 2021.

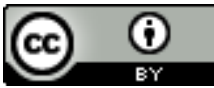

Angles est mise à disposition selon les termes de la Licence Creative Commons Attribution 4.0 International. 


\title{
Operation Warp Speed as a "Moonshot": Some Public Policy Lessons
}

\author{
Nicholas Sowels
}

\section{Introduction}

1 Before the COVID-19 pandemic in early 2020, Donald Trump was fairly well-positioned to win the November elections given the strength of the US economy and very low unemployment (OECD). But then his administration and Mr Trump himself in particular fumbled badly as the pandemic took hold. ${ }^{1}$ Through a combination of bravado (not wearing a mask), denial (repeated declarations that the virus would just go away[Bump]), hare-brained solutions (injecting bleach as a remedy [Rogers et al.]), and party politicking (calls for states to lift restrictions), etc., President Trump managed the crisis poorly. Instead of bringing the country together in a common cause which would surely have helped public policy in facing such a massive challenge, he encouraged divisions with consequences later for vaccine acceptance, as we shall see below. Instead of the US cooperating with countries across the world and international institutions, Mr Trump repeatedly referred to COVID-19 as a "Chinese virus" to stoke antipathy to China, and in July 2020 even announced the United States would leave the WHO (Huang).

2 In the meantime, the US health system - by far the most expensive in the world - was struggling badly in dealing with the spreading pandemic. As refrigerated containers were storing the dead in New York City as the city morgues could not cope with the influx of bodies, high-end private health institutions faced cash shortages because elective treatments were being cancelled: US healthcare seemed "broken" (Hook and Kuchler).

3 Yet despite the pandemonium prevailing in the White House, in May 2020 the Trump administration launched Operation Warp Speed (OWS) to bring out a vaccine for the 
coronavirus by the end of the year, when it was widely believed at the time that it could take several years to create one - if ever. In many ways, OWS was a remarkable success. The US helped several vaccines emerge and its vaccination rollout during the first months of 2021 was largely effective, despite some early problems.

This article proposes to examine the implementation of OWS as an unusual public policy project, bringing together public and private-sector actors, and substantial state funding. In particular, OWS has been referred to as a "moonshot", including by Alex Azar, the former Secretary of Health and Human Resources and architect of the project. Writing in The New York Times in August 2021 to stress the reliability of vaccines and to support the vaccination of US citizens in the face of expanding partisan resistance, he compared OWS to President Kennedy's quest to get an American to the moon in the 1960s (Azar).

5 This article begins by presenting in detail how OWS unfolded as a remarkable public policy project. It then discusses to what extent OWS may be used as an example for government-led projects. Here, the article draws on the work of Mariana Mazzucato, a leading international proponent of "entrepreneurial states", and advocate of governments being more mission-oriented in addressing global challenges. In Mission Economy: A Moonshot Guide to Changing Capitalism (2021), Mazzucato also draws substantially on the lessons of the US's Apollo programme to get to the moon, and how this provides a template for renewed government action today. Yet Mazzucato recognises that while aspects of OWS were highly successful, the vaccine rollout faced initial problems and later ran into partisan resistance. The article then qualifies OWS as a state-led project, using the concept of "disciplined pluralism" developed by British economist John Kay which emphasises how markets provide critical feedback in validating innovation, by rewarding success and sanctioning failure. So, while the US federal government was heavily involved in developing vaccines, OWS also entailed strong competition and selection between many private companies seeking to produce a vaccine. Lastly, this contribution seeks to mobilise elements of the expanding literature on complex systems which provides insights into how public policies operate within complex environments. Such complexity analysis helps understand some of the difficulties the vaccine rollout has faced in the US and elsewhere, notably with the emergence of resistance to vaccination: i.e., following complexity theory, resistance has emerged "bottom up" at local and state level, challenging the federal government's "top down" vaccination campaign, becoming a culture war issue with time.

\section{The launching and organisation of Operation Warp Speed}

6 Writing at the end of April 2020, the Irish journalist Fintan O'Toole summarised the bewilderment of many at the staggering mismanagement of the COVID-19 pandemic in the United States: "the world has loved, hated and envied the US. Now, for the first time, we pity it" (O'Toole). More than a year later, the US - still the world's largest economy (World Bank) - continues to have the world's highest numbers of cases and deaths: respectively (on 7 August 2021) 35.7 million and 616,504, and so ahead of India (with 31.9 million cases and 427,371 deaths) (Johns Hopkins). 
But, at the time Mr O'Toole was writing and Donald Trump was holding his daily press show, the United States was also preparing an ambitious programme to develop a vaccine, or vaccines, at breakneck speed. This was a time - it should not be forgotten - when the world was staggering under the unprecedented experience of lockdowns, and many in the scientific community were warning that it could take years to find a vaccine - if ever - as no vaccine had ever been developed against a coronavirus (Thompson).

Initial discussions for setting up a special project started in April 2020 and were reported at the end of the month (DoD). By then, $\$ 456$ million dollars of federal money had already been committed to the Johnson \& Johnson vaccine for Phase 1 clinical trials (on the $30 \mathrm{March}$ ), and an allocation of $\$ 483$ million in funding was announced on 16 April for Moderna, a relative start-up, to accelerate its vaccine development programme after it had begun Phase 1 trials (DHHSc). However, "frustrated" with warnings by experts like the suddenly-mediatised Dr Anthony Fauci ${ }^{2}$ that it could take 18 months to develop a vaccine, President Donald Trump pushed for the implementation of a more rapid programme (Sanger). Thus, on 15 May 2020, he announced the establishment of Operation Warp Speed (OWS) as a coordinated interagency and public-private partnership programme to finance vaccine research, development, manufacture, and deployment (DHHSa). Its initial objective was "to have substantial quantities of a safe and effective vaccine available for Americans by January 2021." Over time, this objective became more precise - the provision of 300 million doses - though the timing shifted somewhat from "by January", to "as of January". ${ }^{3}$

\section{Political manoeuvrings and project hype}

The drive to set up OWS was largely led by Department of Health and Human Resources (DHHR) Secretary Alex Azar, who had been side-lined by Mr Trump when he put vicePresident Mike Pence in charge of the coronavirus task force at the end of February 2020. Mr Azar's four-week tenure in the position had been controversial, and Mr Pence was to bring the "gravitas" of his office to the job (Diamond \& Cancryn). The latter's more deliberative style did lead to a more ordered approach in the White House, but may have slowed down decision-making while the Vice-President was dealing with $\mathrm{Mr}$ Trump's mercurial behaviour on questions like wearing masks (Diamond \& Cancryn). In response to his weakened position, Secretary Azar and about a dozen officials at the DHHR and the Department of Defense (DoD) then began working on a programme to create a vaccine, quickly labelled "MP2", standing for Manhattan Project 2, with $\mathrm{Mr}$ Azar boldly proclaiming: "If we can develop an atomic bomb in 2.5 years and put a man on the moon in seven years, we can do this this year, in 2020" (Diamond).

Like the initial Manhattan Project, MP2 was to be headed by a scientist and an army general to bring together technical expertise and military organisation. This mirrored the joint organisational responsibility of the programme by the DHHR and the DoD (see below). It led to the appointment of Dr Moncef Slaoui, a scientist and businessman (with Moroccan, Belgian and US nationality), who had been responsible for developing numerous vaccines at GlaxoSmithKline (GSK) until 2017, and four-star General Gustave F. Perna, who, as head of the US Army Material Command, was as an expert in logistics (DHHSa; Baker and Koons). The programme was then renamed to drop the atomic bomb reference. At the suggestion of Dr Peter Marks, a top official at the Food and Drug 
Administration (FDA) and a Star Trek fan, it was baptised Operation Warp Speed, in reference to faster-than-light travel by the Starship Enterprise in the popular sci-fi TV show. This was to catch the imagination of persons involved in the project, as well as of the public (Solender). OWS also received an official seal (see Figure 1).

Figure 1: Official seal of Operation Warp Seed

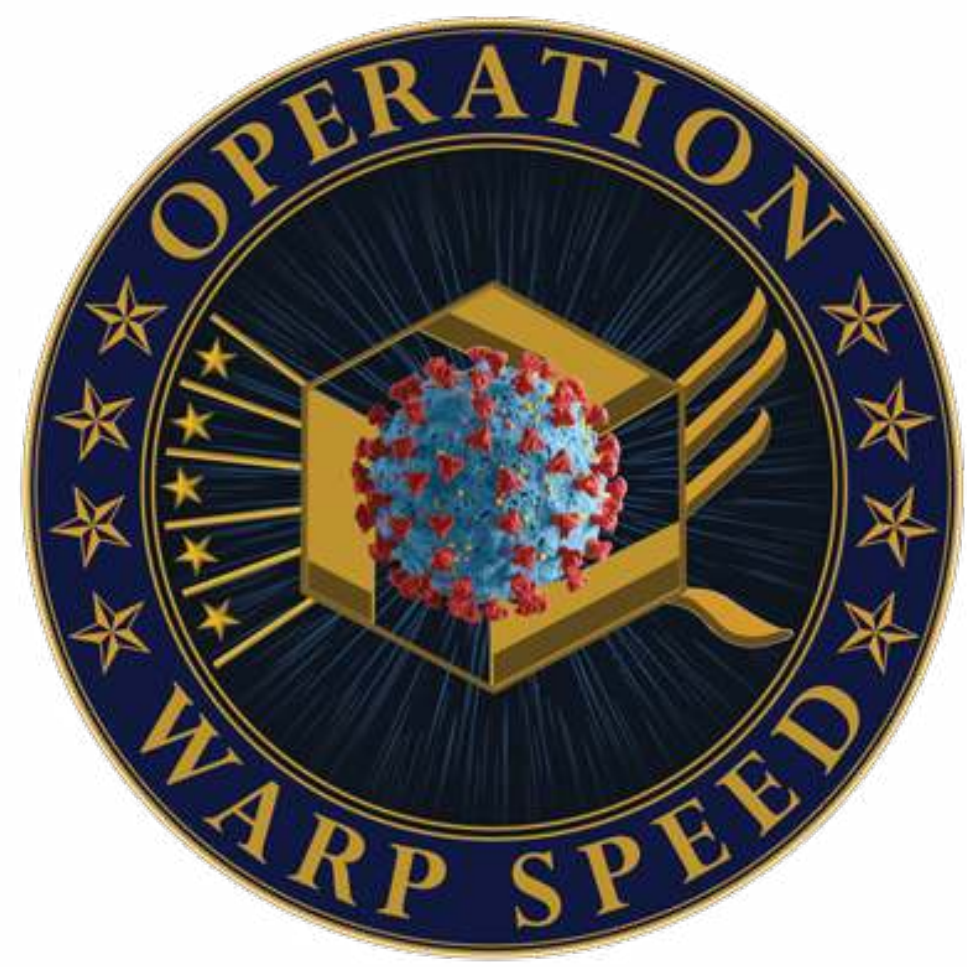

Source: https://en.wikipedia.org/wiki/Operation_Warp_Speed

11 These decisions were not without controversy. In particular, Dr Slaoui was criticised for being employed as a contractor so he could retain shares he owned in GSK, even though the company went on to receive substantial funding under OWS (see below). His response to this was to guarantee to give away any excess capital gains on GSK stocks he would earn, and to give up his position on the board of Moderna and sell his shares in Moderna on taking up his position in OWS (Moderna became one of the first companies to successfully make a vaccine, see Cohen). More significantly perhaps, the name of Operation Warp Speed was also criticised by some (like Dr Fauci), for suggesting that the haste to produce a vaccine could make OWS seem "reckless", and so undermine public confidence (Solender).

Significantly, the leaders of the project were able to limit direct interference in its operations from other parts of government, even from President Trump himself. The latter was obviously keen for the discovery of a safe vaccine to be announced before the November 2020 elections, but Dr Slaoui claims he was able to argue with the President that science could not be managed that way. He also noted that Jared Kushner was supportive on this point (Solender). However, Dr Slaoui expressed concerns at the end of 2020 that the politicisation of OWS during the 2020 elections could weaken its public acceptance. $^{4}$ 


\section{The organisational strengths of Operation Warp Speed}

13 Three key factors explain the success of OWS, according to Thomas Durand, a professor of management at France's CNAM. ${ }^{5}$ The first involved drawing on a variety of existing possible types of vaccines, whatever their origin. Second, OWS re-engineered the traditional sequencing of vaccine production, collapsing early research and clinical trial phases; and third, production of vaccines was launched as testing was still going on (Durand). To these points may be added the management structure of oWS itself, the willingness to commit substantial funding to the search for a vaccine as well as for pre-certification manufacture, and preparations for distributing a vaccine once certified and produced.

14 To achieve its objectives of providing 300 million vaccine doses, OWS initially selected 14 candidate vaccines from more than a hundred, and then narrowed its choice to about eight (DHHSa). These were chosen using four criteria: i) candidate vaccines had to provide data rapidly suggesting safety and efficacy; ii) they had to be able, with ows backing, to enter Phase 3 trials (involving 30,000 persons or more) by the summer or autumn of 2020; iii) they had to use vaccine-platform technologies (i.e., mechanisms or delivery vectors of vaccines) permitting fast and effective manufacturing; and iv) candidate vaccines had to use one of the three vaccine-platform technologies believed to be safe and effective against COVID-19, namely: the mRNA, viral-vector, and protein platforms (Slaoui \& Hepburn). ${ }^{6}$

15 A major aspect of selection was to hedge bets by picking two vaccine candidates per platform: in the words of Moncef Slaoui and Matthew Hepburn of ows, "diversification mitigate[d] the risk of failure due to safety, efficacy, industrial manufacturability or scheduling factors" (Slaoui \& Hepburn). Moreover, the project accepted candidates from anywhere, with no obvious aim of promoting national champions. Or, as Durand has put it:

Pfizer is not a leader in vaccines, BioNTech is a German start-up, founded moreover by two Turkish-immigrant biologists. So what? (Pfizer refused such financing but not a pre-order for 300 million doses). Moderna is an American start-up managed by a Frenchman. So what? It doesn't matter if there are failures, including of Sanofi and GlaxoSmithKline $[. . .]^{7}$

16 Another key factor in OWS's approach was to shorten the sequencing of traditional vaccine development and rollout. This normally involves many steps carried out in order: exploratory science, preclinical trials, clinical trials (Phase 1, Phase 2, and large Phase 3 trials), large-scale manufacturing, and finally review and licensure by the FDA (the Food and Drug Administration). While these steps may involve some overlap, it typically takes 10 years (or longer) to get from exploratory science to large-scale manufacture. In the case of OWS, the whole process was collapsed. In particular, the selection of candidates was done to combine the exploratory and preclinical stages, while the organisation of production began with Phase 1 trials. Here, OWS funding thus covered the risks of losses were vaccines to fail during later trials. As a result, and as the FDA brought forward emergency use authorisation (EUA) during Phase 3 trials, the entire cycle was cut to around 10 months (USGAO). Moreover, apart from financing research and making major pre-orders of doses, OWS was actively involved in expanding the production of ancillary supplies like needles, syringes, glass vials, and vial alternatives, etc. (see Table 2). 
In terms of management, OWS was very much a joint operation shared by the Department of Health and Human Resources (DHHR) and the Department of Defense (DoD), and agencies within these departments, including: the Centers for Disease Control and Prevention (CDC), the FDA, the National Institutes of Health (NIH), the Biomedical Advanced Research and Development Authority (BARDA), and the Defense Advanced Research Projects Agency (DARPA) (DHHSb). In fact, of the 90 persons in leadership positions in OWS in July 2020, about 60 were military officials, including at least four generals. Many of these had never worked in health care before, but they played essential roles in the whole logistical challenge of producing vaccines, which included securing shipments of materials from across the globe, and preparations for the distribution of vaccines in the US (Florko 2020). Private companies like Fedex and UPS have been involved in shipping vaccines, and Mckesson (a medical distribution specialist) held the centralised distributor contract (DHHSb). But control was centralised. In the words of General Perna, "We need to know where every vial was, whether it was in the factory, or it was on a truck, or it had been distributed down to an administration site; we must have $100 \%$ accountability of all vaccines every day" (reported by Lopez). In addition, the military had the task of maintaining the physical security of the production and distribution process, and the cybersecurity of OWS, especially against "state actors" (i.e. foreign governments) who might have wanted it to fail (Florko 2020).

In short, the organisational strength of OWS, which also included about 600 DHHR staff (Florko 2020), was based on the way it brought together actors from the public and private sectors in a public-private partnership. Instead of being a government agency, it was more an ephemeral mechanism to coordinate a multitude of government bodies and many private organisations. As Paul Stoffels, chief scientific officer at Johnson \& Johnson noted, OWS was "a coordination activity that help[ed] cut through the bureaucracy faster" (Baker and Koons).

19 Finally, substantial funding played a huge part in the whole process. Initially when Operation Warp Speed was launched, $\$ 10$ billion was granted to the project through the CARES Act passed in March 2020 to fight the pandemic (DHHSa). With time, the outlays expanded to over $\$ 18$ billion, the vast majority of which went directly to vaccine development and purchase, as well as into supporting manufacture (see Tables 1 and 2). Table 1: Vaccine Contracts and Development Finance by US Authorities (as of 1 March 2021) 


\begin{tabular}{|c|c|c|c|c|c|c|}
\hline Company & Type & $\begin{array}{c}\text { Contract } \\
\text { Value }\end{array}$ & Specifications & $\begin{array}{c}\text { Doses } \\
\text { per } \\
\text { Person }\end{array}$ & $\begin{array}{l}\text { Current Phase } \\
\text { (Preliminary } \\
\text { Effectiveness - } \\
\text { U.S. Strain) }\end{array}$ & Storage \\
\hline Pfizer/BioNTech & mRNA & $\$ 5.97 \mathrm{~B}$ & 300 million doses & 2 & $\begin{array}{l}\text { Phase II/III (95\%) } \\
\text { EUA Issued }\end{array}$ & Ultra cold storage $\left(-70^{\circ} \mathrm{C}\right)$ \\
\hline Moderna & mRNA & $\begin{array}{l}\$ 4.94 \mathrm{~B} \\
\$ 954 \mathrm{M}\end{array}$ & $\begin{array}{l}300 \text { million doses } \\
\text { Development }\end{array}$ & 2 & $\begin{array}{l}\text { Phase III ( } 94.5 \%) \\
\text { EUA Issued }\end{array}$ & $\begin{array}{l}\text { Cold storage }\left(6 \mathrm{mos},-20^{\circ} \mathrm{C}\right) \\
\text { Refrigerator }\left(30 \text { days, }-2^{\circ} \text { to }-8^{\circ} \mathrm{C}\right)\end{array}$ \\
\hline $\begin{array}{l}\text { AstraZeneca/ } \\
\text { Oxford Univ. }\end{array}$ & $\begin{array}{l}\text { Viral } \\
\text { Vector }\end{array}$ & $\$ 1.2 \mathrm{~B}$ & 300 million doses & 2 & Phase II/III (70\%) & Refrigerator $\left(-2^{\circ}\right.$ to $\left.-8^{\circ} \mathrm{C}\right)$ \\
\hline $\begin{array}{l}\text { Johnson \& Johnson } \\
\text { (Janssen } \\
\text { Pharmaceuticals) }\end{array}$ & $\begin{array}{l}\text { Viral } \\
\text { Vector }\end{array}$ & $\begin{array}{l}\$ 1 B \\
\$ 456 M\end{array}$ & $\begin{array}{l}100 \text { million doses } \\
\text { Development }\end{array}$ & 1 & $\begin{array}{l}\text { Phase III (72\%) } \\
\text { EUA Issued }\end{array}$ & Refrigerator $\left(3 \mathrm{mos},-2^{\circ}\right.$ to $\left.-8^{\circ} \mathrm{C}\right)$ \\
\hline Novavax & Protein & $\$ 1.6 \mathrm{~B}$ & 100 million doses & 2 & Phase III (95.6\%) & Refrigerator $\left(-2^{\circ}\right.$ to $\left.-8^{\circ} \mathrm{C}\right)$ \\
\hline Sanofi/GSK & Protein & $\begin{array}{l}\$ 2.04 \mathrm{~B} \\
\$ 30.8 \mathrm{M}\end{array}$ & $\begin{array}{l}100 \text { million doses } \\
\text { Development }\end{array}$ & 2 & Phase $1 / I I$ & Refrigerator $\left(-2^{\circ}\right.$ to $\left.-8^{\circ} \mathrm{C}\right)$ \\
\hline Merck/IAVI & $\begin{array}{l}\text { Viral } \\
\text { Vector }\end{array}$ & $\$ 38 M$ & Development $f^{f}$ & 1 & DISCONTINUED & N/A \\
\hline
\end{tabular}

Source: Congressional Research Service, "Operation Warp Speed Contracts for COVID-19 Vaccines and Ancillary Vaccination Materials", Insight, updated 1 March 2021 (based on data from the DHHR and the DoD).

Table 2: Federal Government Contracts for (Selected) Ancillary COVID-19 Vaccine Supplies (as of 1 March 2021)

\begin{tabular}{|c|c|c|}
\hline Company & Contract Value & Specifications \\
\hline \multirow[t]{2}{*}{ Apilect Systems America } & $\$ 138$ million & 100 million prefilled syringes by the end of 2020 \\
\hline & & $\begin{array}{l}\text { Expansion of manufacturing capacity to produce } 500 \\
\text { million prefilled syringes in } 2021\end{array}$ \\
\hline $\begin{array}{l}\text { Corning Pharmaceutical } \\
\text { Technologies }\end{array}$ & $\$ 204$ million & $\begin{array}{l}\text { Expansion of manufacturing capacity to produce an } \\
\text { additional } 164 \text { million Valor Glass vials per year if } \\
\text { needed }\end{array}$ \\
\hline $\mathrm{SiO} 2$ Materials Science & $\$ 143$ million & $\begin{array}{l}\text { Expansion of manufacturing capacity to produce } 120 \\
\text { million glass-coated plastic containers per year if } \\
\text { needed }\end{array}$ \\
\hline Becton, Dickinson and Co. & $\$ 42.3$ million & $\begin{array}{l}\text { Expansion of manufacturing capacity to produce } \\
\text { needles and syringes }\end{array}$ \\
\hline Smiths Medical, Inc. & $\$ 20.6$ million & $\begin{array}{l}\text { Expansion of manufacturing capacity to produce } \\
\text { needles and syringes }\end{array}$ \\
\hline Goldbelt Security, LLC & $\$ 125$ million & 530 million needles and syringes \\
\hline Retractable Technologies, Inc. & $\$ 53.6$ million & $\begin{array}{l}\text { Expansion of manufacturing capacity to produce safety } \\
\text { needles and syringes }\end{array}$ \\
\hline Retractable Technologies, Inc. & $\$ 93.8$ million & 320 million needles and syringes \\
\hline
\end{tabular}

Source: Congressional Research Service, "Operation Warp Speed Contracts for COVID-19 Vaccines and Ancillary Vaccination Materials", Insight, updated 1 March 2021 (based on data from the DHHR and the DoD).

\section{The results and critiques of Operation Warp Speed}

At the change of presidencies on 20 January 2021, the FDA had granted emergency-use authorisation (EUA) to two vaccines using mRNA technology: the Pfizer/BioNTech and Moderna vaccines. While the AstraZeneca vaccine also received substantial US funding (see Table 1) and was authorised for use in the UK at the end of 2020 and subsequently by the European Medicines Agency, it has not yet been authorised for use in the US. This reflects the vaccine's troubled history with early data difficulties and concerns over very small risks of associated blood clots (Machemer). On 6 August 2021, however, the FDA announced it would allow the export of US-produced doses of the AstraZeneca vaccine (FDA). At the end of February 2021, the FDA also gave EUA to the Johnson \& Johnson (Janssen) vaccine, though this too was amended in late April, again to account 
for very rare blood clots. Finally, in June 2021, Novavax declared that its Phase 3 trial indicated an overall efficacy rate of 90.4 percent, similar to Pfizer/BioNTech and Moderna (Zimmer). Other things being equal, and taking into account efforts throughout the international scientific community (it was estimated, for example, that by end 2020, 200,000 research papers had been published on the coronavirus [Meyerowitz-Katz]), OWS was thus highly successful in supporting the rapid development of vaccines.

21 In terms of the vaccine delivery and rollout, the US Government Accountability Office (GAO, a Congressional office of audit) quotes figures by OWS officials that, as of 31 January 2021, authorised companies had released 63.7 million doses. This was equivalent to 32 percent of the 200 million doses which firms with EUAs had been contracted to provide by 31 March 2021 (USGAO). Yet it was short of the 300 million doses target envisaged in 2020, and the early phases of the rollout in the US were criticised for being slow, characterised by long waiting lines, vaccine registration websites crashing, and health resources being tied up by the January surge of the pandemic (Leathery and Schoenfeld Walker). More specifically, a report by the American Association of Retired Persons published mid-January 2021 points out several problems delaying deployment, including: the unprecedented speed in vaccine development which actually intensified deployment difficulties in itself; the challenge of distributing mRNA vaccines requiring ultra-cold storage; organising flows given the need to ensure second-dose availability; a concentration of OWS efforts on producing vaccines with less attention being paid to their distribution at state-level, where infrastructures were underfunded; problems faced by hospitals in administering vaccines to staff just as the pandemic surged in the winter; resistance by persons to taking vaccines, and bottlenecks arising from allocating vaccines first to priority groups such as long-term care residents and staff (Markowitz).

These early difficulties contributed to the departure of Dr slaoui from the US vaccination effort after the Biden Administration came into office. Dr Slaoui was also criticised for suggesting at one point that only one Moderna dose needed to be administered, after concerns about conflicts of interest, already mentioned above (Weintraub). But, it should be noted that General Perna continued to work under the Biden Administration as Chief Operating Officer of the Federal COVID-19 Response for vaccine and therapeutics, even though he too had been criticised for problems with the vaccine rollout (Lee). More generally, in late March 2021, much of the organisational structure of OWS was still in place (even if its name was dropped), as was the software programme Tiberius $^{8}$ used to track deployment. Instead of scrapping OWS's organisation, the Biden administration tried to make it more effective (Florko 2021).

Indeed, on assuming office, President Biden took a positive and supporting approach to fighting the pandemic, encouraging the wearing of masks, and helping state governments' efforts. On arriving at the White House, his team published a 200-page National Strategy for the COVID-19 Response and Pandemic Preparedness, which committed to vaccinating the US population, and supporting local actors more pro-actively with distribution:

The federal government will execute an aggressive vaccination strategy, focusing on the immediate actions necessary to convert vaccines into vaccinations, including improving allocation, distribution, administration, and tracking. Central to this effort will be additional support and funding for state, local, Tribal, and territorial governments - and improved line of sight into supply - to ensure that they are 
best prepared to mount local vaccination programs. At the same time, the federal government will mount an unprecedented public campaign that builds trust around vaccination and communicates the importance of maintaining public health measures such as masking, physical distancing, testing, and contact tracing even as people receive safe and effective vaccinations (Biden).

Graph 1: Vaccine Doses Delivered per 100 persons in the first half of 2021 (first and second dose combined).

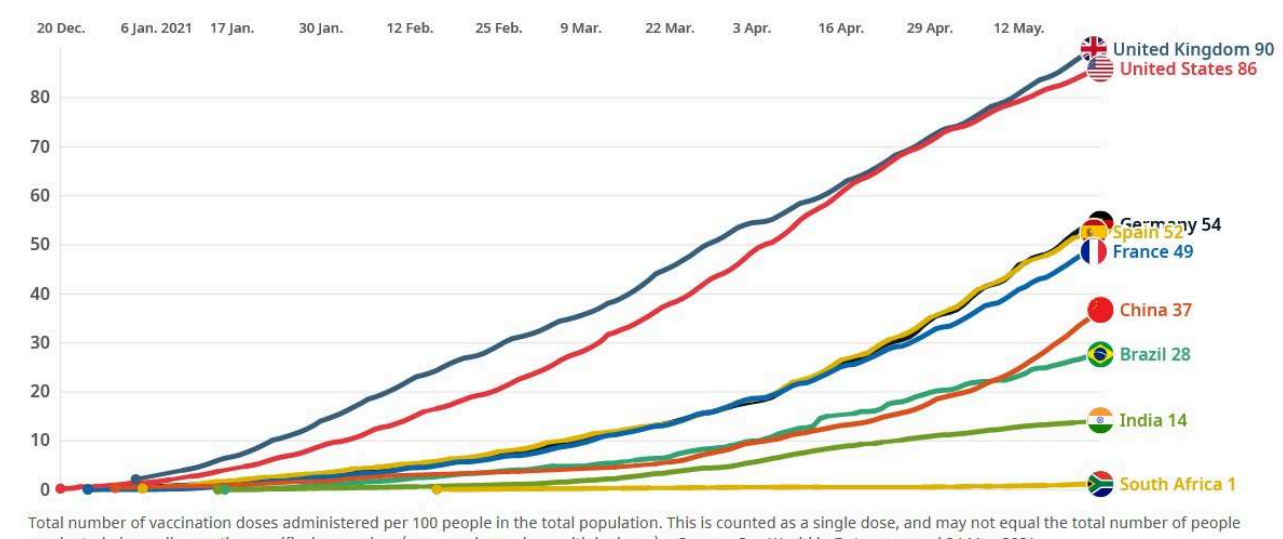

Total number of vaccination doses administered per 100 people in the total population. This is counted as a single dose, and may not equal the total number of people vaccinated, depending on the specific dose regime (e.g. people receive multiple doses). · Source: Our World in Data, accessed 24 May 2021.

Source: OECD, https://www.oecd.org/coronavirus/en/data-insights/eo-2021-05-vaccine-rolloutremains-uneven.

Yet this quote also reveals the complexity of the vaccine deployment process (allocation, distribution, administration and tracking); the variety of jurisdictions involved in the US vaccination programme (state, local, Tribal, and territorial governments); and finally the importance of getting public trust for implementing such a massive public health policy - a task made more difficult by the inconsistencies and politicisation of the vaccine programme (discussed below). All that said, despite early difficulties of the US rollout, Graph 1 shows that the US vaccination campaign did then pick up comparatively very well.

\section{Operation Warp Speed as a Moonshot}

The Trump administration's response to COVID-19 was widely judged as chaotic. Yet OWS was instrumental in supporting the vaccine effort in the US and globally. Here, an attempt is made to analyse in what way OWS may viewed as a successful governmentled moonshot, as proposed by Marina Mazzucato, a leading advocate of state entrepreneurship, and more recently a proponent of mission-oriented public policy. But elements of OWS also support the view that market competition provided the "disciplined pluralism" (John Kay) needed to curtail poor projects which unchecked state support may otherwise have pursued at great cost. Finally, this section examines how complexity analysis can help in examining certain difficulties of the vaccination rollout as a public policy.

\section{The Mission Economy and OWS as a Moonshot}

Mariana Mazzucato is a recognised proponent of the role of government in research and development (R\&D). In 2013, she published The Entrepreneurial State: Debunking 
Public vs. Private Sector Myths, which challenges the prevailing mainstream neoliberal economic orthodoxy that governments are cumbersome and bureaucratic, while only the private sector is risk-taking and innovative. This book identifies how government (in the US especially) has repeatedly acted to support technologies through direct finance or via tax exemptions, and in many cases actually develop them. In doing so, the state "de-risks" private sector activities and addresses market failures like funding basic research, justified even in mainstream economics (Mazzucato 2013). In fact, government has often taken major risks in spearheading the development of new "general purpose technologies", which have been vital to a wide range of sectors, especially in America's "mass production system", including aviation and space technologies, information technology (IT), and more recently life-sciences, nanotechnology, and clean energy industries, and notably the Internet (Mazzucato 2013: 62-3).

In a case study, Mazzucato examines how stated-backed technologies contributed to the launch of Apple Computer in the 1970s, but especially to Steve Job's revival of the firm, beginning with the iPod in the 2000s. Along with its "siblings" - the iPad and iPhone - the iPod revolutionised Apple's fortunes, which had become a niche player in computer technology. Yet, for all the brilliant design and quality of Apple, the core technologies of these new products arose at some point due to government support for hardware (microprocessors, RAMs, hard-drives, lithium-ion batteries, liquid crystal displays, etc.), and for software (HTTP/HTML Internet protocols, SIRI voice recognition, and GPS) (Mazzucato 2013: 87-112).

Apart from recalling the creative role of government, notably in the US, The Entrepreneurial State points to how the benefits of technologies fostered by government accrue to the private sector. Here the book returns to the much-discussed notion after the global financial crisis in 2007-2008 about how neoliberal economics privatises profits and collectivises losses: or in this case, socialises risks. This in turn is connected to how large companies like Apple game the international tax system, with its loopholes and tax havens, to pay very little tax. For Mazzucato, redressing this situation requires changes to tax systems, and new institutions for states to collect investment revenues. But it also requires a new narrative about government's essential role in wealth creation (Mazzucato 2013: 181-91).

With Mission Economy: A Moonshot Guide to Changing Capitalism (2021), Mazzucato takes forward the case for recreating the capacity of states to address major challenges the world faces by adopting "a very different approach to public-private partnerships" (Mazzucato 2021a). The central thesis of this book is that governments need the courage to build up their capacity and to rediscover their confidence in tackling complex "wicked" problems (i.e., problems that are hard, if not impossible to solve, due to complex causalities with multiple, sometimes contradictory consequences) (Mazzucato 2021a: 3). To do so, governments should create organisational systems that address big challenges, notably the pursuit of sustainable development goals, and the green energy transition.

More specifically, in Mission Economy, Mazzucato argues that governments should set up capacities to undertake specific missions or moonshots, in which they are more directly involved as agents and not just purchasers contracting out to the private sector. The template for such an approach to government action is the Apollo programme whose objective President John F. Kennedy proclaimed in 1961 when he called on Congress to 
finance the moon landing by the end of the decade (Kennedy). According to Mazzucato, there are six attributes which defined this project:

(1) vision infused with a strong sense of purpose; (2) risk-taking and innovation; (3) organisational dynamism; (4) collaboration and spillovers across multiple sectors;

(5) long-term horizons and budgeting that focused on outcomes; and (6) a dynamic partnership between the public and private sectors (Mazzucato 2021a: 60).

In the case of Apollo, getting to the moon involved up to 400,000 people and cost $\$ 28$ billion at the time, the equivalent today of $\$ 283$ billion (Mazzucato 2021a: 3 ). This was about 1.1 percent of federal spending, and its mission spread out over more than a decade. The Apollo programme was managed by NASA, a major government bureaucracy, based on the management practices of the time.

So, is Operation Warp Speed an example of the kind of Mission Economy programme which could help reinvigorate The Entrepreneurial State? Was it the moonshot Secretary Azar has claimed? And what lessons does it hold out? In an article for Project Syndicate, Mazzucato states, "the development of Covid-19 vaccines in less than a year was clearly a major achievement. But the rollout has been far from perfect" (Mazzucato 2021c). More specifically, she notes that "Mission-oriented innovation agencies", especially DARPA and BARDA were "critical in seeding the development of cutting-edge mRNA vaccines". This certainly conforms to the role of government in promoting R\&D revealed in her earlier book, while "[t]he collective spirit and outcome-driven approach to vaccine research and development last year recalled the Apollo program" (Mazzucato 2021b). Significantly also was the way OWS supported the manufacture of vaccines. As we have seen above, this began massively during Phase 3 trials. Such early production was instrumental in shortening the emergence of vaccines. But it also meant that public funding was bearing the risk of vaccines being rejected at a later stage. This in turn raises the question of how, and to what extent, the US government should recover some of its investments.

This question is potentially important with respect to Mazzucato's qualified observations about the (global) vaccination process, which she has called an "earthshot": "[w]hile technological breakthroughs can provide new tools, they are not necessarily solutions in themselves. Earthshots require attention to political, regulatory and behavioural changes" (Mazzucato 2021b). Here the clear challenge lies in the disparity between high-income and low-income countries, which risks leading to "vaccine apartheid" across the world (Mazzucato 2021b). Yet, meeting this challenge would require far more resources, in money and personnel. From this point of view, OWS, with its light, flexible structure was a far, far smaller organisation than NASA, with a much lower budget.

\section{"Disciplined pluralism" versus moonshots}

In reviewing Mission Economy, John Kay, a prominent British economist and long-time columnist in The Financial Times, takes a decidedly critical view. Concerning Operation Warp Speed, he notes (writing in January 2021) that the rapid development of vaccines "is, at least provisionally, a success story". But he goes on to state emphatically that the "development is not the product of visionary central direction but is the result of a competitive process with many different teams around the world attempting to be among the first across the finishing line". These teams, Kay argues, drew on "a combination of existing academic science with the expertise in development and 
testing and the manufacturing and logistics capabilities of the global pharmaceutical industry". By contrast, "[t]he role of government, appropriately, [was] primarily in funding basic research and assuring that there will be a rewarding market for successful products" (Kay 2021).

Indeed, Kay's critique of Mission Economy rests much on his concept of "disciplined pluralism", which is guaranteed more by the competitiveness of markets than by government. In The Truth about Markets: their Genius, their Limits and their Follies, a book published in 2003, he argues that innovation is largely a piecemeal process that is hard to guide. In particular, Kay asserts that "[m]ost decisions are wrong. Most experiments fail. It is tempting to believe that if we entrusted the future of our companies, our industries, our countries, to the right people, they would lead us unerringly to the promised land. Such hopes are always disappointed" (Kay 2003: 105). When politicians - or even major business leaders - exercise great power, without appropriate mechanisms for "the recognition of error" (Kay 2003: 357) they frequently get it badly wrong. In fact, in business, "temporary winners [are] almost always displaced as they failed to anticipate the next step of the journey" of innovation (Kay 2021). Kay specifically cites the example of IT. While indeed spurred on by the Apollo programme, IT has been a perpetually changing sector in which yesterday's giants like IBM, and a host of other players such as Digital Equipment, WordPerfect, Wang Laboratories, CompuServe, Netscape, AOL, BlackBerry, etc. have been swept aside by new entrants offering new products and services; even Microsoft has failed to anticipate mobile or cloud computing (Kay 2021). If we apply this observation to OWS, it may be noted that mRNA technology has indeed made two newcomers global players in pharmaceuticals: BioNTech (Pfizer's associate which actually developed the COVID-19 vaccine) and Moderna. By contrast, previous leaders of the vaccine industry like Sanofi and GSK (Dr Slaoui's former company) have yet to produce marketable vaccines (as of August 2021), while work by Merck and the Institut Pasteur, both historical vaccine developers too, was abandoned in January 2021 (Herzberg and Rosier).

Moreover, it is not without some irony that Kay mentions Boris Johnson's own aborted "operation moonshot", launched in September 2020 to create the capacity to test 10 million people per day by early 2021. Here, it was reported that the Prime Minister known for his penchant for big gestures and projects - had asked for "a Manhattan Project-type approach to delivering the level of innovation/pace required to make this possible". Documents about Britain's "Mass Population Testing Plan" suggested costs could have run to a staggering $£ 100$ billion (Booth and Boseley) before plans were integrated into a new, more modest test and trace programme at the end of October 2020.

37 Finally, it should be remembered that for all its spectacular success, getting to the moon was hugely expensive, and once the Americans had won the space race, the Apollo programme was rapidly wound up. The moonshot was wildly exciting. But how useful was it really?

\section{OWS and the complexity of vaccine rollouts}

The challenges of dealing with COVID-19 are far from over and remain complex. From the beginning, managing the pandemic has required making impossible choices. Governments everywhere have had to balance public health objectives with the need to 
keep economies and societies open, while dealing with uncertainties about treatments, a mutating virus, and public scepticism. Moreover, actions by nation states can only go so far: the virus is global, and in a very real sense "no one is safe, until everyone is". ${ }^{9}$

From this point of view, it is useful to go beyond the moonshot/disciplined pluralism approaches presented above (albeit in simplified form), and look at how complexity theory may be applied to OWS and its broader environment. Complexity theory (CT) is a relatively new area of analysis, though organised research on the subject is often identified with the creation of the Santa Fe Institute in 1984. Stated most simply, it seeks to understand complex systems and their interacting or changing elements by going beyond Newtonian causalities (i.e., hard cause-and-effect explanations of phenomena). While CT originated in natural sciences, it has also been applied to social systems, including government, which itself has become far more complex as a result of New Public Management, and the increasing use of partnerships and networks between private and public actors to deliver public services. ${ }^{10}$

Indeed, much work has been done on complexity and public services since the early 2000s, although it is hard to identify an overarching framework and structured set of applications with regards to specific policy areas. That said, some ideas do stand out, apart from a general understanding of the challenges which complexity represents, and awareness of how public policies are tentative, almost by definition, given the permanent evolution of systems and their components parts often leading to the emergence of new phenomena from the "bottom up" in the face of, and independent to, "top down" rules. In contrast to chaotic processes, however, "complex adaptive systems" do have elements of order "as defined by patterns of replicated behaviour for given periods". These are called attractors, and often comprise values, beliefs and behavioural logics (with values playing an especially important role in shaping the evolution of policy). Significantly too, CT examines questions like path dependency which shape the evolution of systems, though so-called bifurcation points also lead to major path changes (Hayes).

41 In terms of OWS, CT may be used to understand the two phases of the operation: vaccine production and the vaccination rollout. Overall, there was little to question the value of producing a vaccine - or vaccines - to fight COVID-19. In spring 2020, lockdowns swept across the world with spectacular speed, massively changing the daily lives of nearly everyone, with drastic consequences for social behaviour, psychological health, and economic activity worldwide. Meanwhile, health systems approached breaking point everywhere. In terms of complexity theory, the case for creating vaccines was a clear attractor in mobilising resources and OWS was the most substantial programme to meet this challenge in the West (though China's efforts on vaccination have been significant, and Russia's Sputnik $\mathrm{V}$ appears to be an effective vaccine, see Jones and Roy). Nor was OWS alone, as it should be recalled that BioNTech and Oxford University were supported by the German and British governments respectively to produce the Pfizer and AstraZeneca vaccines. Nevertheless, these vaccines also benefited from large US orders. More generally, once the strategic choices of oWS had been made on vaccine selection, they too functioned as attractors, while the shortened sequencing of vaccine development manifests elements of both bifurcation from existing practices, and subsequently path dependency: mRNA technology in particular has considerable potential for vaccine research. 

developing its comparatively successful vaccination rollout. Donald Trump stands out as one of the few political leaders who deliberately pursued a divisive approach to managing the pandemic: for much of 2020 he did little to coordinate the US's federal, state and local systems of government around policies that could have acted as attractors in dealing with the pandemic (such as wearing masks). Far from trying to bring some coherence to the response of the US's public-private and decentralised health system to the pandemic, the Trump White House exacerbated controversies, setting significant sections of US society on the path to vaccine resistance in 2021 . The launch and pursuit of OWS was therefore arguably a fortunate bifurcation point following its own logic, with the development of vaccines being relatively isolated from direct political interference by the White House.

\section{Conclusion}

Operation Warp Speed was in many ways a remarkable success. It supported the ultrarapid, international development of several vaccines in 2020, which were used to bring down infection rates and cases of severe COVID-19 in the world's rich countries in 2021. OWS's organisation was both focussed and flexible, bringing together several government agencies - including from the US military - and very many private sector actors. It may be seen both as government-led moonshot, and as a project drawing on 
competition among private actors to produce vaccines. There are thus lessons here for how governments may organise ambitious public-private partnerships in meeting specific challenges. But OWS was far more limited in time and resources than the Apollo programme. Its objectives and successes were strongly focussed, while its organisational structure was light. Moreover, much of the science used was already in place, including mRNA technology. Broader, more complex objectives may be less amenable to this approach: for example, an article published by Time in May 2021 calls for a similar programme to tackle depression, based on the assumption that recent science has established clear biological causes and treatments to address this widespread and varied condition (Schrobsdorff). That may be true. Yet, as Kay has also noted, the Nixon administration tried to fight cancer using the Apollo project as a model... and failed because of the complexity of the disease (Kay 2021). "Wicked problems" cannot always be solved - even by moonshot efforts.

The OWS experience also shows up the problems of moving from developing innovative technologies to applying them widely across society, let alone throughout the world. Even when the initial difficulties with vaccine deployment were overcome, the resistance to vaccination in the US (and elsewhere) indicates the problems linked to achieving broader changes, despite the tangible effectiveness of instruments (in this case vaccines). Moreover, despite the evident successes of several vaccines and the mastery of their production, the world's rich countries have - so far - failed to set up a worldwide vaccination effort (Brown). Estimates for the cost of a global programme run to $\$ 80$ billion, and much less if patents are released (Inman): though this may entail risks to the quality of production. This would be far cheaper than the Apollo programme, and would be in the rich countries' own interests, for as long as CovID-19 rages across the planet the more chances there are for the emergence of new, hard-totreat variants. But the political will is lacking at present.

\section{BIBLIOGRAPHY}

Asthana, Anushka. "What went wrong with Covid-19 response in the US?" Audio interview with Lawrence Wright. The Guardian, 14 June 2021. https://www.theguardian.com/news/audio/2021/ jun/14/what-went-wrong-with-the-us-covid-19-response-podcast

Azar, Alex. "I Was the Architect of Operation Warp Speed. I Have a Message for All Americans." Guest Essay, The New York Times, 3 August 2021. https://www.nytimes.com/2021/08/03/opinion/ covid-vaccine-safety.html

Baker, Stephanie, and Cynthia Koons, “Inside Operation Warp Speed's \$18 Billion Sprint for a Vaccine”, Bloomberg, 29 October 2020. https://www.bloomberg.com/news/features/2020-10-29/ inside-operation-warp-speed-s-18-billion-sprint-for-a-vaccine

Biden Jr, Joseph. National Strategy for the Covid-19 Response and Pandemic Preparedness. January 2021, p 8. https://www.whitehouse.gov/wp-content/uploads/2021/01/National-Strategy-for-theCOVID-19-Response-and-Pandemic-Preparedness.pdf 
Booth, Robert, and Sarah Boseley. "Boris Johnson pinning hopes on $£ 100$ billion 'moonshot' to avoid second lockdown.” The Guardian, 9 September 2020. https://www.theguardian.com/world/ 2020/sep/09/boris-johnson-pinning-hopes-on-covid-testing-moonshot-leaked-papers-show

Brown, Gordon. "Despite the grand words, this G7 falls devastatingly short on vaccines." The Guardian, 14 June 2021. https://www.theguardian.com/commentisfree/2021/jun/14/grandwords-g7-vaccines-summit-failure-gordon-brown

Bump, Philip. "Yet again, Trump pledges that the coronavirus will simply go away." The Washington Post, 28 April 2020. https://www.washingtonpost.com/politics/2020/04/28/yet-againtrump-pledges-that-coronavirus-will-simply-go-away/

Cohen, Jon. "Proud of vaccine success, Warp Speed's ex-science head talks politics, presidents, and future pandemics." Interview with Dr Moncef Slaoui, Science, 25 Jan. 2021. https:// www.science.org/content/article/proud-vaccine-success-warp-speed-s-ex-science-head-talkspolitics-presidents-and-future

Congressional Research Service. "Operation Warp Speed Contracts for Covid-19 Vaccines and Ancillary Vaccination Materials.” Insight, updated 1 March 2021. https:// crsreports.congress.gov/product/pdf/IN/IN11560

DoD, Department of Defense. Coronavirus Timeline. https://www.defense.gov/Explore/Spotlight/ Coronavirus/Timeline/ (accessed 8 June 2021).

DHHSa Press Office. "Trump Administration Announces Framework and Leadership of 'Operation Warp Speed'." Press release, 15 May 2020. https://www.hhs.gov/about/news/2020/05/15/trumpadministration-announces-framework-and-leadership-for-operation-warp-speed.html

DHHSb. From the Factory to the Frontlines: The Operation Warp Speed Strategy for Distributing a Covid-19 Vaccine. 23 September 2020. https://www.hsdl.org/?abstract\&did=844253

DHHSc. Explaining Operation Warp Speed, consolidated fact sheet explaining OWS, 14 December 2020. https://web.archive.org/web/20201219231756/https://www.hhs.gov/coronavirus/ explaining-operation-warp-speed/index.html

Diamond, Dan. “The crash landing of 'Operation Warp Speed'”, Politico, 17 January 2021. https:// www.politico.com/news/2021/01/17/crash-landing-of-operation-warp-speed-459892

Diamond, Dan, and Adam Cancryn. "How Mike Pence slowed down the coronavirus response." Politico, 26 August 2020.

Durand, Thomas. "Vaccin contre le Covid-19: 'L'opération Warp Speed, un succès américain'." Le Monde, 16 April 2021. https://www.lemonde.fr/idees/article/2021/04/16/vaccin-contre-lecovid-19-1-operation-warp-speed-un-succes-americain_6077029_3232.html

FDA. “Coronavirus (COVID-19) Update: August 6, 2021.” 6 August 2021. https://www.fda.gov/ news-events/press-announcements/coronavirus-covid-19-update-august-6-2021

Florko, . "New document reveals scope and structure of Operation Warp Speed and underscores vast military involvement." Stat, 28 Sept. 2020. https://www.statnews.com/2020/09/28/ operation-warp-speed-vast-military-involvement/

Florko, Nicholas. "The operation formerly known as Warp Speed: Biden leans heavily on the flagship Trump-era initiative.” Stat, 30 March 2021. https://www.statnews.com/2021/03/30/ operation-formerly-known-as-warp-speed-biden-leans-on-trump-era-initiative/

French, David. “How Can We Escape the Covid-19 Vaccine Culture Wars?" Time (online), 8 June 2021. https://time.com/6071909/covid-19-vaccine-culture-war/ 
Gray, Kathleen. "In Michigan, a Dress Rehearsal for the Chaos at the Capital on Wednesday." The New York Times, 9 January 2021. https://www.nytimes.com/2021/01/09/us/politics/michiganstate-capitol.html

Haynes, Philip. Managing Complexity in the Public Services. London, Routledge, 2015.

Herzberg, Nathaniel, Florence and Rosier. "Covid-19 : pourquoi l'Institut Pasteur a abandonné son principal projet de vaccin.” Le Monde, 26 January 2021. https://www.lemonde.fr/sante/ article/2021/01/26/covid-19-l-institut-pasteur-abandonne-son-principal-projet-devaccin_6067654_1651302.html

Hook, Leslie, and Hannah Kuchler. "How coronavirus broke America's healthcare system." The Financial Times, 30 April 2020. https://www.ft.com/content/3bbb4f7c-890e-11ea-a01ca28a3e3fbd33

Huang, Pien. “Trump Sets Date to End WHO Membership Over Its Handling of Virus." NPR, 7 July 2020. https://text.npr.org/888186158

Inman, Phillip. "Covid vaccine programme for developing countries could cost just $\$ 6.5$ bn." The Guardian, 11 June 2021. https://www.theguardian.com/society/2021/jun/11/covid-vaccineprogramme-for-developing-countries-could-cost-just-65bn

John Hopkins, Coronavirus Resource Center. https://coronavirus.jhu.edu/map.html (accessed 16 June 2021).

Jones, Ian, and Polly Roy. "Sputnik V Covid-19 vaccine candidate appears safe and effective." Comment, The Lancet, 397. 10275 (20 February 2021): 642-643. DOI: 10.1016/S0140-6736(21)00191-4

Kay, John. “The Truth about Markets: their Genius, their Limits and their Follies.” London: Allen Lane, Penguin, 2003.

Kay, John. "Mission Economy by Mariana Mazzucato - could moonshot thinking help fix the planet?” The Financial Times, 13 January 2021. https://www.ft.com/content/

86475b94-3636-49ec-9b3f-7d7756350b30

Kennedy Center (The). JFK's Famous Speech to Congress on Space Exploration (1961). https:// www.youtube.com/watch?v=8ygoE2YiHCs

Khazan, Olga. "The Tucker Carlson Fans Who Got Vaxxed.” The Atlantic, 9 August 2021. https:// www.theatlantic.com/politics/archive/2021/08/why-so-many-republicans-wont-get-vaccinated/ 619659/

Kolata, Gina. "Moncef Slaoui, the former head of Operation Warp Speed, was fired from a biotech company after sexual misconduct allegations." The New York Times, 24 March 2021. https:// www.nytimes.com/2021/03/24/science/moncef-slaoui-allegations.html

Leatherby, Lauren, and Amy Schoenfeld Walker. "After a Sluggish Start, Vaccine Rollout Is Improving in Every State.” The New York Times, 12 February 2021. https://www.nytimes.com/ interactive/2021/02/12/us/vaccine-doses-distribution.html

Lee, Bruce Y. “Operation Warp Speed's General Perna Apologizes For Covid-19 Vaccine Delivery Shortfalls." Forbes, 20 December 2020. https://www.forbes.com/sites/brucelee/2020/12/20/ operation-warp-speeds-general-perna-apologizes-for-covid-19-vaccine-delivery-shortfalls/

Lopez, C. Todd. "In Warp Speed Effort, Knowing Where Vaccines Are Is Key to Distribution Strategy." U.S. Department of Defense News, 28 October 2020. https://www.defense.gov/News/ News-Stories/Article/Article/2395789/in-warp-speed-effort-knowing-where-vaccines-are-iskey-to-distribution-strategy/ 
Machemer, Theresa. "Why U.S. Approval of the AstraZeneca Covid-19 Vaccine Is Taking So Long." SmartNews: Smithsonian Magazine, 29 March 2021. https://www.smithsonianmag.com/smartnews/revised-astrazeneca-data-show-its-covid-19-vaccine-76-percent-effective-180977356/ Mabin, Matthieu. "Covid-19: La découverte du vaccin, c'est le début de la fin de la pandémie." L'Entretien-France 24, 4 December 2020. https://www.france24.com/fr/émissions/l-entretien/ 20201204-covid-19-la-découverte-du-vaccin-c-est-le-début-de-la-fin-de-la-pandémie

Markowitz, Andy, and American Association of Retired Persons (AARP). "7 Reasons the COVID-19 Vaccine Rollout Has Been Slow.” 14 January 2021. https://www.aarp.org/health/conditionstreatments/info-2021/slow-covid-vaccine-rollout.html

Meyerowitz-Katz, Gideon. "Science matters. The remarkable response to Covid has reminded us." The Guardian, 30 December 2020. https://www.theguardian.com/commentisfree/2020/dec/30/ science-matters-the-remarkable-response-to-covid-has-reminded-us

Mazzucato, Mariana. The Entrepreneurial State: Debunking Public vs. Private Sector Myths. London: Anthem Press, 2013.

Mazzucato, Mariana. Mission Economy: A Moonshot Guide to Changing Capitalism. London: Allen LanePenguin, 2021a.

Mazzucato, Mariana. "From Moonshots to Earthshots." Project Syndicate, 3 February 2021b. https://www.project-syndicate.org/commentary/moonshots-earthshots-state-investment-inthe-public-interest-by-mariana-mazzucato-2021-02

Mazzucato, Mariana. "Build Back the State." Project Syndicate, 15 April 2021c. https:// www.project-syndicate.org/commentary/biden-lessons-from-us-moonshot-by-marianamazzucato-2021-04

Morin, Edgar. "Restricted Complexity, General Complexity." In Carlos Gershenson, Diederik Aerts, Bruce Edmonds eds. Worldviews, Science and Us: Philosophy and Complexity. New Jersey/ London: World Scientific, 2007. 5-29. http://www.cogprints.org/5217/1/Morin.pdf

OECD. Economic Outlook. November 2019, country summary for the United States. https:// www.oecd.org/economic-outlook/november-2019/ (accessed 4 August 2021).

O'Toole, Fintan. "Donald Trump has destroyed the country he promised to make great again." The Irish Times, 25 April 2020. https://www.irishtimes.com/opinion/fintan-o-toole-donald-trumphas-destroyed-the-country-he-promised-to-make-great-again-1.4235928

Reuters. "AstraZeneca weighs seeking full, not emergency, US approval for Chovid-19 shot WSJ. 7 May 2021. https://www.reuters.com/world/us/astrazeneca-weighs-seeking-full-usapproval-covid-19-shot-wsj-2021-05-07/

Rogers, Katie, Christine Hauser, Alan Yuhas, and Maggie Haberman. “Trump's Suggestion That Disinfectants Could Be Used to Treat Coronavirus Prompts Aggressive Pushback." The New York Times, 24 April 2021. https://www.nytimes.com/2020/04/24/us/politics/trump-injectdisinfectant-bleach-coronavirus.html

Sanger, David E. “Trump Seeks Push to Speed Vaccine, Despite Safety Concerns.” The New York Times, 29 April 2020. https://www.nytimes.com/2020/04/29/us/politics/trump-coronavirusvaccine-operation-warp-speed.html

Schrobsdorff, Susanna. "Depression Is a Pandemic. Let's Use the Lessons of COVID-19 to Find Treatments." Time, 17 May 2021. https://time.com/6048942/why-we-need-a-mental-healthmoonshot-for-depression-in-the-wake-of-the-pandemic/ 
Slaoui, Moncef, and Matthew Hepburn. "Developing Safe and Effective Covid Vaccines Operation Warp Speed's Strategy and Approach." Perspective, The New England Journal of Medicine 383 (12 October 2020): 1701-1703. DOI: 10.1056/NEJMp2027405

Smith, David. "Republican leaders fiddle while Covid burns through their own supporters." The Guardian, 14 August 2021. https://www.theguardian.com/us-news/2021/aug/14/republicanleaders-fiddle-while-covid-burns-through-their-own-supporters

Solender, Andrew. “Fauci Worries ‘Operation Warp Speed' Fuels Perception Vaccine Is Being Rushed." Forbes, September 8, 2020. https://www.forbes.com/sites/andrewsolender/2020/09/08/ fauci-worries-operation-warp-speed-fuels-perception-vaccine-is-being-rushed/

Sowels, Nicholas. “A Brief Introduction to Complexity Theory in Managing Public Services.” In Emma Bell, Clémence Fourton, and Nicholas Sowels eds. Public Services in the UK: the Ongoing Challenges of Delivery and Public Accountability. Revue de la civilisation britannique 36.2 (2021). DOI: 10.4000/rfcb.7801

Thompson, Stuart A. "How Long Will a Vaccine Really Take?" The New York Times, 30 April 2020. https://www.nytimes.com/interactive/2020/04/30/opinion/coronavirus-covid-vaccine.html

USGAO, United States Government Accountability Office (GAO). Operation Warp Speed: Accelerated COVID-19 Vaccine Development Status and Efforts to Address Manufacturing Challenges. Report to Congressional Addressees, 11 February 2021. https://www.gao.gov/products/gao-21-319

Wagner, Dennis. "The COVID culture war: At what point should personal freedom yield to the common good?" USA Today, 2 August 2021. https://eu.usatoday.com/story/news/nation/ 2021/08/02/covid-culture-war-masks-vaccine-pits-liberty-against-common-good/5432614001/

Webber, Tammy, and Emily Swanson. "AP-NORC poll: Most unvaccinated Americans don't want shots." Apnews, 23 July 2021. https://apnews.com/article/joe-biden-science-health-governmentand-politics-coronavirus-pandemic-36ea18ee3a3397da7edd5b8249f0e477

Weintraub, Arlene. "Warp Speed chief Slaoui resigns at Biden's request as COVID-19 shots are unleashed: report." Fierce Pharma, 13 January 2021. https://www.fiercepharma.com/pharma/ warp-speed-chief-slaoui-resigns-at-biden-s-request-as-covid-19-vaccines-are-unleashed-report

World Bank Data, GDP (current US\$),2020, https://data.worldbank.org/indicator/ NY.GDP.MKTP.CD

Zimmer, Carl. "Novavax Offers U.S. a Fourth Strong Covid-19 Vaccine." The New York Times, 14 June 2021. https://www.nytimes.com/2021/06/14/health/covid-vaccine-novavax.html

\section{NOTES}

1. For a discussion of the Trump administration's handling of the pandemic see Asthana (2021).

2. Dr Anthony Fauci is the Director of the National Institute of Allergy and Infectious Diseases. He was often seen awkwardly standing beside President Trump during his daily press conferences, sometimes correcting the latter.

3. The various versions of the DHHS fact sheet (Explaining Operation Warp Speed) reflect the changing dates of the 300 million dose target.

4. The risks of politicisation affecting OWS were discussed by Dr Moncef Slaoui in an interview (in French) with Matthieu Mabin (2020).

5. The Conservatoire national des arts et métiers (CNAM) is France's leading educational institution for life-long learning. 
6. "The messenger RNA (mRNA) vaccines contain harmless virus genetic material that codes for a protein that is found on the virus's surface. The body recognizes this protein as foreign and initiates an immune response [...] [T] he viral vector vaccines contain a weakened version of the live virus that has most of the harmful parts of the COVID-19 genetic code removed [...] [and the p]rotein subunit vaccines contain harmless pieces of the COVID-19 virus (protein), which the body recognises as foreign and mounts an immune response against" (Congressional Research Service 2021).

7. "Pfizer n'est pas leader dans les vaccins, BioNTech est une start-up allemande, qui plus est fondée par deux biologistes turcs immigrés ? Et alors? (Pfizer refusera les financements, mais pas une précommande de 300 millions de doses). Moderna est une start-up américaine dirigée par un Français, et alors? Peu importe qu'il y ait des échecs, y compris de Sanofi et de GlaxoSmithKline [...]" (Durand), translation mine.

8. The system's name comes from James Tiberius Kirk, captain of the Enterprise in the original Star Trek TV series.

9. This idea has been repeatedly asserted, amongst others, by the UN and its affiliate associations like UNICEF.

10. For a presentation of how complexity analysis has emerged in sciences and social sciences see Edgar Morin. For a general presentation of complexity and public policy see Nicholas Sowels (2021).

\section{ABSTRACTS}

This article presents Operation Warp Speed (OWS), a federal government project launched by the Trump administration in May 2020 to develop a vaccine against COVID-19. In contrast with the often incoherent and sometimes reckless behaviour of President Trump during the pandemic, OWS was a focussed and largely successful initiative to support vaccine research, manufacture, and delivery. It contributed to the discovery and early deployment of several vaccines within a year and paved the way for a comparatively effective vaccination campaign in the United States in 2021, which later met popular resistance along partisan lines. The article examines OWS as a public-private partnership to achieve a "moonshot", drawing on Mariana Mazzucato's work on Mission Economics which calls for more pro-active government action to tackle major economic, environmental, and social challenges. The article then qualifies the success of ows as a moonshot, pointing to the competitive market elements built into the project which also helped ensure its success. Finally, this research strives to examine OWS and the US vaccination rollout using complexity analysis, to give some perspective to the emergence of vaccine resistance behaviour as of spring 2021.

Cet article présente l'Opération Warp Speed (OWS), un programme fédéral lancé par l'administration Trump en mai 2020 pour développer un vaccin contre le COVID-19. Contrairement à la réponse souvent incohérente et parfois irresponsable du Président Trump pendant la pandémie, l'ows fut un programme très ciblé et réussi pour soutenir la recherche, la fabrication et la livraison de vaccins, qui a contribué à la découverte et au déploiement rapides de plusieurs vaccins en moins d'un an. De même, l'ows a ouvert la voie à une campagne de vaccination relativement réussie aux États-Unis en 2021, qui par la suite s'est heurtée à une obstruction partisane au sein de la population. L'article examine ensuite l'ows en tant que 
partenariat public-privé avec un «objectif lune» en s'inspirant des travaux de Mariana Mazzucato sur L'économie de mission qui prône des politiques publiques plus volontaristes pour aborder des problèmes économiques, environnementaux et sociaux majeurs. Cette contribution avance aussi quelques mises en garde contre une approche aussi ambitieuse, soulignant que le fonctionnement de l'OWS s'appuya aussi sur les lois du marché pour le développement de vaccins. Enfin, l'article cherche à examiner l'ows et le programme de vaccination aux États-Unis à la lumière de la théorie de la complexité qui fournit des pistes pour comprendre l'émergence de la résistance partisane au programme de vaccination qui s'est développé à partir du printemps 2021.

\section{INDEX}

Keywords: Operation Warp Speed, COVID-19, coronavirus, vaccines, moonshots, disciplined pluralism, complexity theory, public policy, Trump Donald, Mazzucato Mariana, Kay John

Mots-clés: Operation Warp Speed, COVID-19, coronavirus, vaccins, moonshots, pluralisme discipliné, théorie de la complexité, politique publique, Trump Donald, Mazzucato Mariana, Kay John

\section{AUTHOR}

\section{NICHOLAS SOWELS}

Maître de conférences $\mathrm{HC} /$ Senior Lecturer at the Université Paris 1 Panthéon-Sorbonne, member of PHARE (Paris1) and associate member of CREW (Paris 3). He teaches English for economics, political economy and developments in finance in the United States and the United Kingdom. His research includes public policy, Brexit and finance, current issues in the evolution of capitalism, as well as poverty and inequality in the United Kingdom. Contact: nicholas.sowels [at] univparis1.fr 